\title{
A Takayasu's Arteritis Case with Unilateral Digital Clubbing
}

\author{
Tek Taraflı Çomak Parmağ ${ }_{1}$ Olan Bir Takayasu Arteriti Olgusu
}

\author{
Mahmut ÇİVİLİBAL, ${ }^{1}$ Nilgün SELÇUK DURU, ${ }^{2}$ Gafur DOĞDU, ${ }^{2}$ Murat ELEVLİ, ${ }^{2}$ Semih AYTA ${ }^{1}$ \\ ${ }^{1}$ Departments of Pediatric Clinic, Haseki Education and Research Hospital, İstanbul, Turkey; \\ ${ }^{2}$ Departments of Pediatrics, Haseki Education and Research Hospital, Ístanbul, Turkey
}

\begin{abstract}
Takayasu arteritis is a large vessel vasculitis that usually affects young female patients during the second and third decades of life. Less commonly, it can also be seen childhood. In this article, we describe a case of Takayasu arteritis in a 17 year-old-boy who presented with unilateral digital clubbing. The patient had also a one-month history of muscle weakness and myalgia in the left upper and lower extremity. There was no hypertension or abdominal bruit. Digital subtraction angiography revealed a total occlusion of the left subclavian artery and a severe narrowing of the right renal artery. The association of digital clubbing and Takayasu's arteritis is not common. To our knowledge, only two cases have been reported to date.
\end{abstract}

Key words: Digital clubbing, digital subtraction angiography, hypertension, Takayasu arteritis.

Takayasu arteritis (TA) is a chronic large vessel systemic granulomatous vasculitis primarily involving the aorta and its major branches. ${ }^{[1,2]}$ The disease usually affects young woman, but it can also be seen less commonly in childhood. Variable degrees of narrowing, occlusion, dilatation or aneurysm develop in the involved vessel segments due to inflammation, leading to a wide range of symptoms..$^{[3-5]}$ The majority of pediatric patients with TA present during adolescence. ${ }^{[6]}$

At an early stage of TA, there are nonspecific systemic findings such as hypertension, fatigue, fever, muscle pain, arthralgias and weight loss. If untreated, the disease progresses to a chronic phase in which the patients present with clinical symptoms of limb and organ ischemias. ${ }^{[5]}$
Takayasu arteriti genellikle yaşamın ikinci ve üçüncü on yılında genç kadınları etkileyen bir büyük damar vaskülitidir. Daha az sıklıkta çocukluk çağında da görülebilir. Bu yazıda tek taraflı çomak parmağı olan Takayasu arteritli 17 yaşındaki bir erkek olgu sunuldu. Hastanın sol üst ve alt ekstremitelerinde bir aydan beri devam eden kas zayıflığı ve miyaljisi vardı. Hipertansiyon ve abdominal üfürüm yoktu. Dijital subtraksiyon anjiyografide sol subklaviyan arterde total tıkanma ve sağ renal arterde ciddi daralma olduğu görüldü. Çomak parmak ve Takayasu arteriti birlikteliği yaygın değildir. Bilgilerimize göre bugüne kadar yalnız iki olgunun sunumu yapılmıştır.

Anahtar sözcükler: Çomak parmak; dijital subtraksiyon anjiyografi; hipertansiyon; Takayasu arteriti.

Digital clubbing associated with TA is very rare. To our knowledge, only two cases with this association have been reported to date. ${ }^{[7,8]}$ Our case is of particular interest because it involves the youngest patient with TA and digital clubbing.

\section{CASE REPORT}

The patient was a 17-year-old boy who presented with left digital clubbing. He had suffered from muscle weakness and myalgia in his left arm and leg for two months before admission. He had been admitted to a local hospital 10 days previously. The patient was referred to our hospital for neurologic evaluation. The pain persisted at that moment. His past and family medical histories were unremarkable. 
On admission, the patient appeared well. He was alert and afebrile. His weight and height were on the $25^{\text {th }}$ and $10^{\text {th }}$ percentiles, respectively. The blood pressure was $115 / 75 \mathrm{mmHg}$, and there was not a difference in blood pressure between the two arms. The pulse was $100 /$ minute and respiratory rate 25/minute. No significant lymphadenopathy or organomegaly was noticed. Cardio-respiratory, abdominal and neurologic examinations were unremarkable. Bilaterally carotid, femoral, posterior tibial, dorsalis pedis, the right brachial and radial pulses were normal; however, the left radial and brachial pulses were weak. There was no bruit audible on auscultation over neck and abdomen. Digital clubbing was noted in the left hand (Figure 1).

Laboratory investigations were as follows: white blood count 13.900 cells $/ \mathrm{mm}^{3}$ (cell differential: neutrophils, 79.1\%; lymphocytes, 16.7\%; monocytes, 4.2\%); hemoglobin level $8.6 \mathrm{~g} /$ dl, platelet count $724.000 / \mu 1$, ASO 3200 Todd Ü, erythrocyte sedimentation rate $101 \mathrm{~mm} / \mathrm{hr}$, and
CRP $156 \mathrm{mg} / \mathrm{dl}$. Serum creatine, transaminases, electrolytes, complements titer, thyroid functions and urinalysis were normal. Autoantibodies including rheumatoid factor (RF), anti-nuclear antibody (ANA), anti-ds DNA, p-ANCA, c-ANCA and anti-ENA (antiRo, anti-La, anti-Sm, anti-RNP, anti-Scl-70 and antiJo-1) were all negative. Viral serology for toxoplasma, Ebstein-Barr virus, cytomegalovirus, parvovirus, human immunodeficiency virus and hepatitis screen were negative. Blood cultures were also negative. Radiographs of the upper and lower extremities, chest X-ray, and tomography and echocardiography were normal. Doppler ultrasound of four extremities revealed a decreasing blood flow in the left brachial, radial and ulnar arteries. Magnetic resonance imaging (MRI)-angiography showed a total occlusion of the left subclavian artery and a severe narrowing of the right renal artery. Subsequently, he underwent a digital subtraction aortogram and bilateral selective renal arteriography. The digital subtraction angiography revealed total occlusion in the left subclavian artery and superior mesenteric artery. A severe narrowing
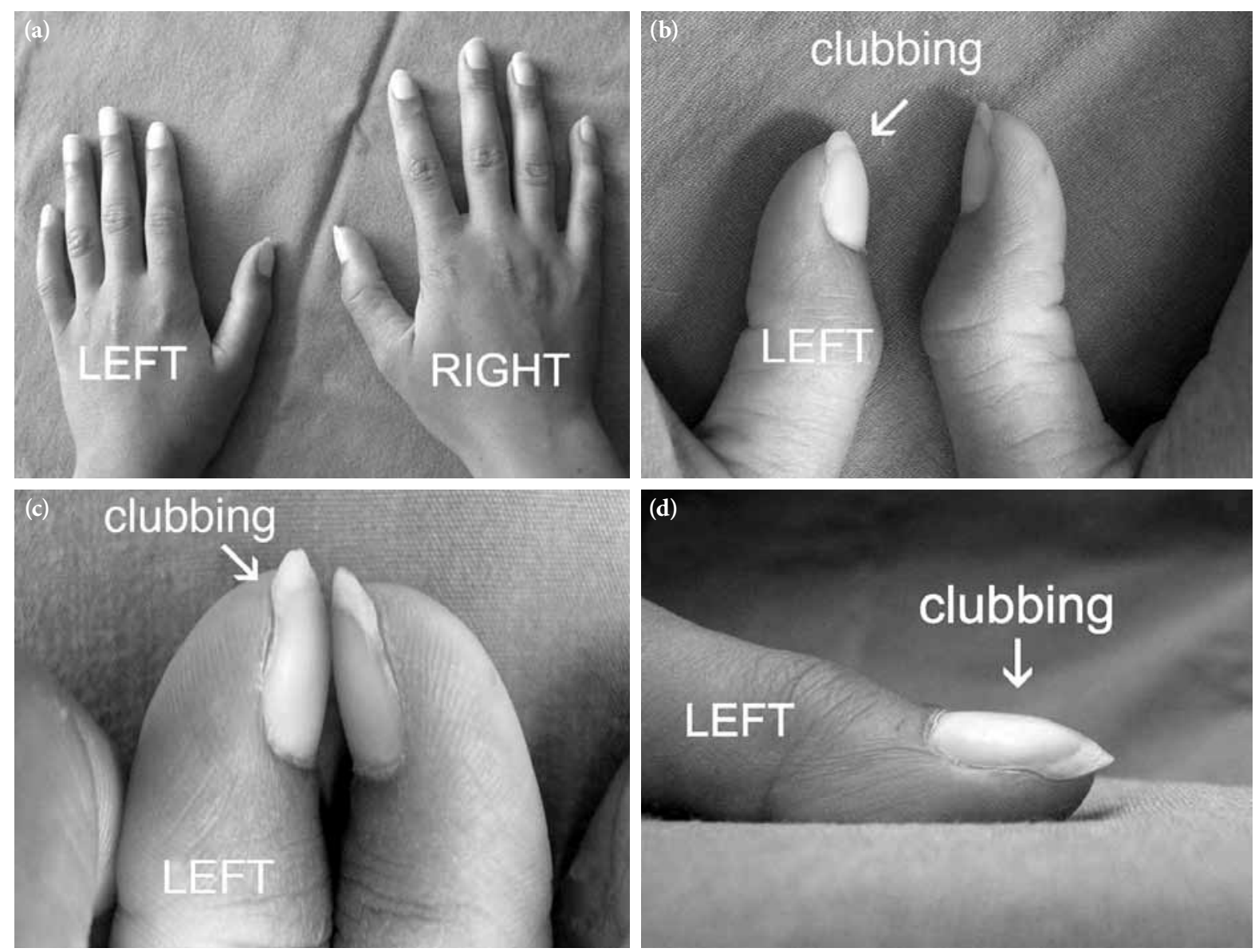

Figure 1. The patient, a 17-year-old boy with Takayasu arteritis, presented with a unilateral digital clubbing. (a) Photographs show digital clubbing in the fingers of the left hand and (b-d) in the first finger of the left hand. 

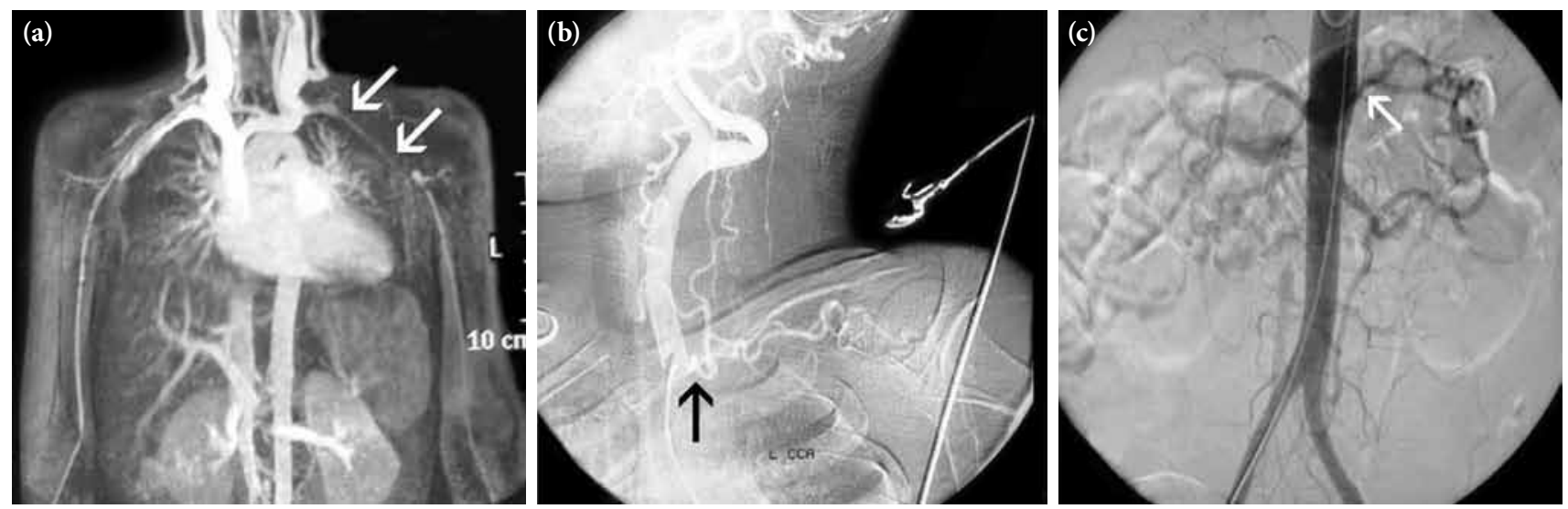

Figure 2. Magnetic resonance imaging angiography (a) and digital subtraction angiography (b) show complete occlusion from the origin of the left subclavian artery (white and black arrow, respectively). (c) Selective renal arteriography reveals a severe narrowing (90-95\% stenosis) at the proximal segment of the right renal artery (white arrow).

(90-95\% stenosis) was detected in the proximal segment of the right renal artery. Technetium-99mdimercaptosuccinic acid (DMSA) scintigraphy was performed for quantitative assessment of the renal functions separately, and it was consistent with a function of $59 \%$ in the right kidney and $41 \%$ in the left kidney.

He was diagnosed as having TA. The boy was given immunosuppressive (prednisolone, azothiopurine) therapy. Hypertension occurred late in his clinical course; his blood pressure was 156/89 and 130/75 $\mathrm{mmHg}$ on her right arm and left arm, respectively. We added extended-release nifedipine $(30 \mathrm{mg} /$ day $)$ as antihypertensive therapy. Surgery was planned; intravascular stent placement of the right renal artery was performed by balloon angioplasty. Digital clubbing was improved by immunosuppressive therapy after three months.

\section{DISCUSSION}

As reported above, an adolescent showed the typical feature of digital clubbing in association with TA. There are only two adult reports describing digital clubbing in patients with TA. ${ }^{[7,8]}$

The criteria for diagnosing TA defined by the American College of Rheumatology ${ }^{[9]}$ included six items: (i) age of onset younger than 40 years; (ii) claudication of extremities; (iii) decreased pulsation of one or both brachial arteries; (iv) difference of at least $10 \mathrm{mmHg}$ systolic pressure between arms; $(v)$ bruits over one or both subclavian arteries or the abdominal aorta; (vi) arteriographic narrowing or occlusion of the entire aorta, its primary branches, or large arteries in the proximal upper or lower extremities not caused by arteriosclerosis, fibromuscular dysplasia, or other causes. The diagnosis is most likely when three of these six criteria are met. ${ }^{[9]}$ Our case met criteria (i), (ii), (iv) and (vi); therefore, he fulfilled the criteria for TA.

The common manifestations of TA are hypertension, lower and upper extremity claudication, abdominal angina and pulselessness depending on the type of involvement. During childhood the disease usually manifests itself with hypertension, congestive heart failure, secondary hypertrophic cardiomyopathy and congestive hepatomegaly. The major causes of morbidity and mortality are the cardiovascular and cerebrovascular complications of uncontrolled hypertension. ${ }^{[3,9]}$ The largest series reported by Hong et al. $^{[10]}$ noted that arterial hypertension was seen in $65 / 70$ patients (93\%). In other reports, similar findings were found. ${ }^{[11,12]}$ Our case did not have hypertension because he could have been in the early inflammatory phase of disease on admission.

Diagnosis of TA is challenging in the early inflammatory phase when only non-specific symptoms are present, and imaging is nondiagnostic. Although conventional angiography is the gold standard for TA imaging, it is invasive and cannot detect thickened vessel walls, an early sign of inflammation. MRIangiography and positron emission tomography (PET)-scan can detect luminal diameter changes and disparities in vessel metabolic activity, respectively, which are indicative of early inflammation. ${ }^{[6,13]}$

In our case, digital clubbing developed at an early stage of TA. It is thought that clubbing occurred due to subclavian artery stenosis and the subsequent circulatory disturbance in the peripheral tissues. Since clubbing occurred ipsilaterally with the progression 
of subclavian artery stenosis and resolved after the commencement of immunosuppressive therapy, it is suggested that the digital clubbing occurred in association with stenosis resulting from vascular inflammation. The pathogenesis of these lesions is not yet known. It is well known that digital clubbing manifests both connective tissue and vascular changes. It is believed to be stimulated by platelet-derived growth factor (PDGF) which leads to the proliferation of connective tissue. ${ }^{[14]}$ Several mechanisms have been proposed by which platelet clumps accumulate in the fingertips and release PDGF. Hepatocyte grow th factor is another potential stimulator of clubbing. ${ }^{[15]}$ Sridhar et al. ${ }^{[16]}$ found higher levels of HGF in lung cancer patients with clubbing than in those without clubbing, suggesting that HGF may play a role in the formation of digital clubbing. Atkinson and Fox ${ }^{[17]}$ suggested that vascular endothelial growth factor (VEGF) and PDGF expression is hypoxically enhanced after capillary occlusion and that VEGF may synergize with PDGF in inducing stromal and vascular changes present in digital clubbing. It is reasonable to suggest that the same growth factors play an important role in the pathogenesis of digital clubbing in our patients as well.

Although clubbing is not common in the presence of subclavian artery stenosis, it probably occurred in our patient because of severe vascular inflammation with the rapid progression of stenosis. Digital clubbing was improved by immunosupressive therapy. The clubbing may have been improved as a result of increased blood flow, but it is also possible that the symptoms were improved by the inhibition of the release of cytokines such as PDGF, VEGF or HGF by immunosupressive therapy.

In conclusion, digital clubbing is very rare in TA. The etiology of this condition remains unknown. Tissue hypoxemia, arteriovenous shunts and cytokines can be related to digital clubbing, but their role is still speculative. Some patients with TA can be without hypertension, especially in early clinical course. Thus, digital clubbing in a child or adolescent should alert the clinician for the possible diagnosis of TA, even if his blood pressure is normal.

\section{Declaration of conflicting interests}

The authors declared no conflicts of interest with respect to the authorship and/or publication of this article.

\section{Funding}

The authors received no financial support for the research and/or authorship of this article.

\section{REFERENCES}

1. Magge SN, Chen HI, Stiefel MF, Ernst L, Cahill AM, Hurst R, et al. Multiple ruptured cerebral aneurysms in a child with Takayasu arteritis. J Neurosurg Pediatr 2008;1:83-7.

2. Kim TJ, Uhm WS, Song SY, Jun JB. Unilateral weak radial pulse in a patient with systemic sclerosis: Takayasu's arteritis or thoracic outlet syndrome? Rheumatol Int 2007;27:789-90.

3. Civilibal M, Sever L, Numan F, Altun G, Ocak S, Candan C, et al. Dissection of the abdominal aorta in a child with Takayasu's arteritis. Acta Radiol 2008;49:101-4.

4. Kausman JY, Walker A, Piper S. Acute panuveitis and Takayasu's arteritis. Arch Dis Child 2003;88:938-9.

5. Al Abrawi S, Fouillet-Desjonqueres M, David L, Barral X, Cochat P, Cimaz R. Takayasu arteritis in children. Pediatr Rheumatol Online J 2008;6:17.

6. Weiss PF, Corao DA, Pollock AN, Finkel TH, Smith SE. Takayasu arteritis presenting as cerebral aneurysms in an 18 month old: A case report. Pediatr Rheumatol Online J 2008;6:4

7. Kaditis AG, Nelson AM, Driscoll DJ. Takayasu's arteritis presenting with unilateral digital clubbing. J Rheumatol 1995;22:2346-8.

8. Ishikawa M, Okada J, Kondo H. Takayasu's arteritis with transient clubbed finger. Clin Exp Rheumatol 1999;17:629-30.

9. Arend WP, Michel BA, Bloch DA, Hunder GG, Calabrese LH, Edworthy SM, et al. The American College of Rheumatology 1990 criteria for the classification of Takayasu arteritis. Arthritis Rheum 1990;33:1129-34.

10. Hong CY, Yun YS, Choi JY, Sul JH, Lee KS, Cha SH, et al. Takayasu arteritis in Korean children: clinical report of seventy cases. Heart Vessels Suppl 1992;7:91-6.

11. Hahn D, Thomson PD, Kala U, Beale PG, Levin SE. A review of Takayasu's arteritis in children in Gauteng, South Africa. Pediatr Nephrol 1998;12:668-75.

12. Cakar N, Yalcinkaya F, Duzova A, Caliskan S, Sirin A, Oner A, et al. Takayasu arteritis in children. J Rheumatol 2008;35:913-9.

13. Melo NC, Sette LH, Coelho FO, Lima-Verde EM, Santana AN, Praxedes JN. Clinical images: Hypertension due to otherwise asymptomatic, complete aortic occlusion in Takayasu arteritis. Arthritis Rheum 2009;60:312.

14. Dickinson CJ, Martin JF. Megakaryocytes and platelet clumps as the cause of finger clubbing. Lancet 1987;2:1434-5.

15. Hojo S, Fujita J, Yamadori I, Ezaki T, Watanabe S, Yamanouchi $\mathrm{H}$, et al. Hepatocyte growth factor and digital clubbing. Intern Med 1997;36:44-6.

16. Sridhar KS, Lobo CF, Altman RD. Digital clubbing and lung cancer. Chest 1998;114:1535-7.

17. Atkinson S, Fox SB. Vascular endothelial growth factor (VEGF)-A and platelet-derived growth factor (PDGF) play a central role in the pathogenesis of digital clubbing. J Pathol 2004;203:721-8. 